\title{
Effect of including different levels of crude glycerin in feed on plasma triglyceride concentrations in pigs, and the composition and qualitative attributes of pork
}

\section{Efeito dos níveis de inclusão de glicerina bruta sobre as concentrações plasmáticas de triglicerídeos em suínos, composição e características qualitativas da carne suína}

\author{
Paulo Levi de Oliveira Carvalho ${ }^{1 *}$; Tiago Junior Pasquetti²; Liliane Maria Piano \\ Gonçalves ${ }^{3}$; Lina María Peñuela Sierra ${ }^{4}$; Thaline Maira Pachelli da Cruz ${ }^{5}$; Silvana \\ Teixeira Carvalho ${ }^{6}$; Jansller Luiz Genova ${ }^{7}$; Aparecida da Costa Oliveira ${ }^{8}$
}

\begin{abstract}
This study was conducted to evaluate the effects of including two types of crude glycerin (CG) in feed on plasma parameters, quantitative and qualitative carcass characteristics, and the fatty acid profile of the Longissimus dorsi pig muscle. Sixty-three commercial line pigs were used, with an average weight of $30.53 \pm 1.59$ to $59.55 \pm 4.27 \mathrm{~kg}$ in the growing phase and $60.35 \pm 2.25$ to $89.91 \pm 5.23 \mathrm{~kg}$ in the finishing phase. The pigs' diet included two sources of CG (vegetable and mixed) at four inclusion levels $(3 \%, 6 \%, 9 \%$ and $12 \%)$. One CG was derived from soybean oil (VCG) and the other from $80 \%$ animal fat $+20 \%$ soybean oil (MCG). The control diet contained $0 \%$ glycerin. Blood samples were collected at the beginning, middle and final phases of the trial. In addition, at the end of the finishing phase, the animals were fasted for $12 \mathrm{~h}$ and then sacrificed to measure the quantitative and qualitative carcass characteristics and the fatty acid profile of the Longissimus dorsi. The results indicate that in both phases there was a quadratic effect on plasma triglycerides. There was no effect on carcass parameters. A quadratic behaviour for $\mathrm{pH}_{24 \mathrm{~h}}$ was obtained, with the lowest value attained at $1.05 \% \mathrm{CG}$ inclusion. There was an interaction between the type of glycerin and the inclusion level in the diets for polyunsaturated fatty acids. VCG and MCG can be used at up to $12 \%$ inclusion because they cause no negative effects on carcass characteristics and pig meat quality.
\end{abstract}

Key words: Biodiesel. Blood parameters. By-product. Fatty acid profile. Glycerin. Meat quality.

\footnotetext{
1 Prof., Universidade Estadual do Oeste do Paraná, UNIOESTE, Marechal Cândido Rondon, PR, Brasil. E-mail: paulolevi@ yahoo.com.br

2 Prof., Universidade Estadual do Mato Grosso do Sul, UEMS, Aquidauana, MS, Brasil. E-mail: pasquettizoo@yahoo.com.br

3 Doutorado em Zootecnia, Universidade Estadual de Maringá, UEM, Maringá, PR, Brasil. E-mail: liliane_piano@hotmail.com

${ }^{4}$ Prof ${ }^{a}$, Universidad del Tolima, UT, Ibagué, TOL, Colômbia. E-mail: linapenuela@gmail.com

5 Discente de Doutorado em Ciência Animal e Pastagens, Universidade de São Paulo, USP, São Paulo, SP, Brasil. E-mail: thalinempc@hotmail.com

6 Prof ${ }^{a}$, UNIOESTE, Marechal Cândido Rondon, PR, Brasil. E-mail: silteixeira@gmail.com

7 Mestrado em Zootecnia, UNIOESTE, Marechal Cândido Rondon, PR, Brasil. E-mail: jansllerg@gmail.com

8 Pós-Doutorado em Zootecnia, UNIOESTE, Marechal Cândido Rondon, PR, Brasil. E-mail: aparecidacostaoliveira@gmail.com

* Author for correspondence
} 


\section{Resumo}

Este estudo foi conduzido para avaliar os efeitos de inclusão de dois tipos de glicerina bruta (GB) sobre os parâmetros plasmáticos, características quantitativas e qualitativas da carcaça, e o perfil de ácido graxo do músculo Longissimus dorsi de suínos. Foram utilizados 63 suínos de linhagem comercial, com um peso médio de $30,53 \pm 1,59$ a 59,55 $\pm 4,27 \mathrm{~kg}$ na fase de crescimento e $60,35 \pm 2,25$ a 89,91 $\pm 5,23 \mathrm{~kg}$ na fase de terminação. A dieta dos suínos incluiu duas fontes de GB (Vegetal e Mista) com quatro níveis de inclusão (3, 6, 9 e 12\%). Uma GB foi derivada de óleo de soja (GBV) e outra de $80 \%$ de gordura animal $+20 \%$ de óleo de soja (GBM). A dieta controle continha $0 \%$ de glicerina. Amostras de sangue foram coletadas nas fases inicial, intermediária e final do estudo. Além disso, ao final da fase de terminação, os animais permaneceram em jejum por $12 \mathrm{~h}$ e foram sacrificados para mensurar as características quantitativas e qualitativas da carcaça e o perfil de ácido graxo do Longissimus dorsi. Os resultados indicam em ambas as fases, houve um efeito quadrático nos triglicerídeos plasmáticos. Não houve efeito sobre os parâmetros de carcaça. Um comportamento quadrático para $\mathrm{pH}_{24 \mathrm{~h}}$ foi obtido, com o menor valor atingido em 1,05\% de inclusão de GB. Houve interação entre os tipos de glicerina e os níveis de inclusão nas dietas para ácidos graxos poli-insaturados. A GBV e a GBM podem ser usados em até $12 \%$ de inclusão porque não causam efeitos negativos nas características de carcaça e na qualidade da carne de suínos.

Palavras-chave: Biodiesel. Parâmetros sanguíneos. Co-produto. Perfil de ácido graxo. Glicerina. Qualidade de carne.

\section{Introduction}

In Brazilian pig farming, corn comprises $65-70 \%$ of the feed supply. It is a valuable highcost grain that is also used in human food. Hence, its replacement in animal diets by other energy sources is an interesting option to reduce the costs of pig production.

Thus, the need arises for the study of new foods and nutritional strategies that contribute to better metabolic functioning of pigs, and becomes indispensable to their production. Among the corn replacement alternatives, crude glycerin (CG) stands out due to its high availability, high energy and low prices (EGEA et al., 2016). Glycerin is the main co-product of biodiesel production, considered as a carbohydrate fraction with $10-11 \%$ triglycerides by weight (CERRATE et al., 2006).

In its chemical composition, CG oil contains unreacted catalyst and a high percentage of methanol. It has a sweet taste which is well accepted by the animals. In the liver, glycerin is converted to glucose by gluconeogenesis, hence it is a highly available energy source (KERR et al., 2009). CG has an advantage over a pure or refined source because it does not need purification treatments, which have an excessively high cost for small and medium domestic biodiesel producers (RIVALDI et al., 2007).

Early studies concerning the use of glycerin to feed pigs were performed in the 1990s in Europe, to evaluate the effects of glycerin derived from various raw materials and its purification levels on performance, carcass characteristics and meat quality of pigs. Thus, research aimed at the inclusion of up to 5\% CG in feed for pigs in the growth and finishing stages highlights a trend to decrease adverse qualitative carcass characteristics such as drip loss and cooking loss (MOUROT, 2009; MOUROT et al., 1993), alterations in the fatty acid profile of the meat, and fat thickness (KIJORA; KUPSCH, 1996; MOUROT et al., 1994).

For this reason, we aimed to evaluate the effects of including two types of CG (vegetable and mixed) in feed on plasma parameters, quantitative and qualitative carcass characteristics, and the fatty acid profile of the Longissimus dorsi pig muscle (30 to $90 \mathrm{~kg})$. 


\section{Materials and Methods}

Animal care

All procedures involving animals were approved by the $\mathrm{MCT} / \mathrm{CNPq} / \mathrm{FNDCT}$ Transversal Action (Edital 30/2008) - Process 574589/2008-2, in conformity with the Brazilian guidelines for the care and handling of animals used for scientific purposes.

Experimental design, animals, housing and dietary treatments

Initially, 63 commercial line pigs (TOPIGS Genetic) were used, with an average weight of $30.53 \pm 1.59 \mathrm{~kg}$ initial and $59.55 \pm 4.27 \mathrm{~kg}$ final in the growing phase; later, other animals started the finishing experiment with an average weight of $60.35 \pm 2.25 \mathrm{~kg}$ initial and $89.91 \pm 5.23 \mathrm{~kg}$ final in the finishing phase. The experiment was conducted in the Swine Sector of the Experimental Farm of Iguatemi, belonging to the Centre of Agrarian Sciences at the State University of Maringá (CCA/ UEM), in the state of Paraná, Brazil ( $23^{\circ} 21^{\prime} \mathrm{S}, 52^{\circ}$ 04' W, $564 \mathrm{~m}$ altitude). The average minimum and maximum temperatures recorded in the trial were $20.7 \pm 1.58$ and $29.7 \pm 2.64{ }^{\circ} \mathrm{C}$, respectively, and the relative humidity $(\mathrm{RH})$ of the air in the morning and the afternoon was $87.3 \pm 8.73 \%$ and $68.4 \pm 13.62 \%$ $\mathrm{RH}$, respectively. The total rainfall in the period was $918 \mathrm{~mm}$.

The inclusion of two sources of CG in pig food was studied: VCG - derived from vegetable oil (soybean); and MCG - mixed, approximately $80 \%$ animal fat $+20 \%$ soybean oil. The experimental design was a randomized complete block design with a $2 \times 4$ factorial analysis scheme, two types of glycerol (VCG and MCG) and four inclusion levels ( $3 \%, 6 \%, 9 \%$ and $12 \%)$, with seven replicates and one pig per experimental unit, that is, eight treatments and seven replicates per treatment, totalling 56 animals. In addition, a control diet (CD), containing $0 \%$ glycerin, was formulated, using seven more animals to give a total of 63 animals used per experimental phase.

The diets were formulated based on corn and soybean meal to meet the recommendations provided by Rostagno et al. (2011), for pigs from 30-60 kg live weight for the growth phase and from 60 to 90 $\mathrm{kg}$ for the finishing phase. In the formulations, the metabolizable energy values for VCG and MCG were 4,480 and $4,710 \mathrm{kcal} \mathrm{kg}^{-1}$ of natural material, respectively, as obtained previously (CARVALHO et al., 2013). For corn and soybean meal, crude protein, phosphorus and calcium were determined.

\section{Food analysis}

The chemical composition and energy of the glycerides (VCG and MCG) were determined by measuring density, moisture content (Karl Fischer method) and total glycerol at the Instituto de Tecnologia do Paraná (Tecpar). The $\mathrm{pH}$, protein, minerals and raw energy (adiabatic calorimeter Parr Instrument Co. AC720) were obtained at the Laboratory of Food Analysis and Animal Nutrition at the State University of Maringá, according to the procedures described by Silva and Queiroz (2002). The sodium chloride content was determined at the Biopar Analysis Control Laboratory. Non-glycerol organic material (MONG) was calculated according to the equation indicated by Hansen et al. (2009), where $\mathrm{MONG}=100-(\%$ glycerol $+\%$ moisture $+\%$ ash).

The VCG and MCG results were, respectively: 1090 and $1110 \mathrm{~kg} \mathrm{~m}^{-3}$ density, $2.54 \%$ and $5.45 \%$ moisture, $\mathrm{pH} 8.75$ and $8.55,0.05 \%$ and $0.05 \%$ crude protein, 83.22 and 82.33 ppm calcium, 203.25 and $167.51 \mathrm{ppm}$ phosphorus, 0.174 and $0.023 \mathrm{ppm}$ potassium, 1.620 and $1.990 \mathrm{ppm}$ sodium, 3.52\% and $3.01 \%$ sodium chloride, $55.95 \%$ and $55.45 \%$ glycerol, $37.43 \%$ and $34.48 \%$ MONG, and 5,247 and $5,242 \mathrm{kcal} \mathrm{kg}^{-1}$ gross energy (CARVALHO et al., 2012). 
Determination of total lipids and the fatty acid profile (Table 1) was performed by chromatography in the Departments of Chemistry and Physics, respectively, at the State University of Maringá. VCG and MCG were solids at room temperature, with high levels of fatty acids, making it difficult to mix in the remaining feed ingredients. Therefore, it was necessary to pre-heat the CG at a controlled temperature $\left(30-40{ }^{\circ} \mathrm{C}\right)$, according to Bligh and Dyer (1959).

Table 1. Crude glycerin fatty acids composition (g/100 g lipid).

\begin{tabular}{lcc}
\hline \multirow{2}{*}{ Fatty acids } & \multicolumn{2}{c}{ Glycerin } \\
\cline { 2 - 3 } & Crude vegetal & Crude mixed \\
\hline Total lipids, \% & 23.30 & 21.50 \\
$\mathbf{1 4 : 0}$ (myristic acid) & 0.30 & 0.47 \\
$\mathbf{1 6 : 0}$ (palmitic acid) & 11.52 & 16.2 \\
$\mathbf{1 6 : 1 n - 7}$ (palmitoleic acid) & $<0.1$ & $<0.1$ \\
$\mathbf{1 8 : 0}$ (stearic acid) & 4.25 & 6.77 \\
$\mathbf{1 8 : 1 n - 9}$ (oleic acid) & 24.01 & 26.69 \\
$\mathbf{1 8 : 1 n - 7}$ (vaccenic acid) & 1.47 & 1.81 \\
$\mathbf{1 8 : 2 n - 6}$ (linoleic acid) & 52.67 & 41.06 \\
$\mathbf{1 8 : 3 n - 3}$ (a-linolenic acid) & 5.95 & 4.00 \\
\hline
\end{tabular}

\section{Plasma parameters}

At the beginning (baseline), middle $\left(20^{\text {th }}\right.$ day for growing and $14^{\text {th }}$ day for finishing $)$ and final $\left(38^{\text {th }}\right.$ and $36^{\text {th }}$ days for growing and finishing, respectively) phases of the trial, blood samples were collected via the cranial vena cava. The samples were stored in tubes containing heparin, except for those for the plasma glucose analyses that were stored in tubes containing a mixture of sodium fluoride and potassium oxalate. The blood was centrifuged $(3,000$ rpm, $15 \mathrm{~min}$ ) to obtain the plasma, and then three aliquots, in duplicate, were transferred to Eppendorf tubes and stored $\left(-18{ }^{\circ} \mathrm{C}\right)$ for subsequent analyses. For biochemical cholesterol, glucose, triglyceride and plasma urea nitrogen (PUN) analysis, commercial reagent kits were used (Gold Analisa Diagnóstica Ltda), and the quantities of all the blood components were determined by absorbance measured using a Bioplus 2000 spectrophotometer. The baseline results obtained at the beginning of the experiment were used as a covariate for analysis.

\section{Carcass and meat quality measures}

At the end of the finishing phase, the animals were fasted for $12 \mathrm{~h}$. They were then sacrificed at the slaughterhouse at the Experimental Farm of Iguatemi/UEM, according to the humane slaughter protocol. The animals walked to the slaughterhouse, which is located $15 \mathrm{~m}$ from the pig sector. After evisceration, the carcasses were split longitudinally in half, identified, weighed, and the $\mathrm{pH}$ of the $L$. dorsi measured in the hot carcass at 45 min postmortem $\left(\mathrm{pH}_{45 \text { min }}\right)$ using a Portable Digital HI 99163 $\mathrm{pH}$ meter (Hanna Instruments). The $\mathrm{pH}$ meter was calibrated using buffer solution ( $\mathrm{pH} 4.01$ and 7.0). The equipment probe has an internal temperature sensor, the calibration solutions and samples being at the same temperature. The measurement at $45 \mathrm{~min}$ was at room temperature, and the $24-\mathrm{h}$ refrigeration was at approximately 2 to $3{ }^{\circ} \mathrm{C}$. Soon after, the carcasses were stored in refrigerated chambers $( \pm$ $2{ }^{\circ} \mathrm{C}$ ) where they remained for $24 \mathrm{~h}$ to allow rigor mortis to develop. 
After cooling, the $\mathrm{pH}$ was measured $\left(\mathrm{pH}_{24 \mathrm{~h}}\right) ; \mathrm{pH}$ measurements were performed on $L$. dorsi between the $12^{\text {th }}$ and $13^{\text {th }}$ thoracic vertebra. Also, the L. dorsi muscle area and fat thickness were determined using SPRING software (CÂMARA et al., 1996). Then, for qualitative evaluation of the carcass, the L. dorsi muscle was removed from the $8^{\text {th }}$ and $10^{\text {th }}$ regions and divided into $\sim 2.5-\mathrm{cm}$ thick samples, coded for identification, placed in polyethylene bags and stored $\left(-18{ }^{\circ} \mathrm{C}\right)$. However, colour, marbling and consistency were evaluated immediately after removing the samples from the chilled carcasses. Assessments of carcass characteristics were performed according to methods previously described (BRIDI; SILVA, 2009).

The CIELAB L* (lightness), a* (red-green component) and $b^{*}$ (yellow-blue component) colour parameters of the muscle surface were determined from six measurements using a Konica Minolta CR-400 portable colorimeter (settings: illuminant D65; $0^{\circ}$ viewing angle and 4 self-average); prior to evaluation, L. dorsi samples were exposed to the air for a period of $20 \mathrm{~min}$, allowing their oxygenation. Simultaneously, a subjective colour assessment regarding consistency and marbling was performed using a five-point scale ( $1=$ pale, soft and devoid of marbling; 5 = dark, moderate, or heavy, firm marbling), as described by the NPPC (1991).

Cooked L. dorsi samples (100 g), approximately 2.5-cm thick, were used to determine the shear force (Newtons). For cooking, the oven was first heated for 20 min at $170^{\circ} \mathrm{C}$. The samples were roasted until the internal temperature reached $40{ }^{\circ} \mathrm{C}$ (measurement with a skewer thermometer). The samples were then turned and kept in the oven until they reached an internal temperature of $71{ }^{\circ} \mathrm{C}$. Samples were then removed from the oven and kept until they reached room temperature. In each sample, the $L$. dorsi was removed along the muscle fibre direction, and five cylindrical subsamples (diameter $1.27 \mathrm{~cm}$ ) prepared, according to the recommendations of Ramos and Gomide (2007).
Analyses were performed using a Stable Micro System TA-XT2i texturometer, equipped with a Warner-Bratzler device, and Texture Expert Exponent software (Stable Micro Systems) (BRIDI; SILVA, 2009).

The extraction process of fatty acids was efficient; approximately $1.81 \%$ of intramuscular fat was extracted. The fatty acids were trans-esterified according to Bragagnolo and Rodriguez-Amaya (2002), and the fatty acid profile analysed by gas chromatography (Shimadzu GC-14B). The column temperature was initially set at $165^{\circ} \mathrm{C}$ for $18 \mathrm{~min}$, then increased at $30{ }^{\circ} \mathrm{C} \mathrm{min}^{-1}$ to $180{ }^{\circ} \mathrm{C}$, maintained at $180{ }^{\circ} \mathrm{C}$ for $22 \mathrm{~min}$, and finally heated at $15^{\circ} \mathrm{C}$ $\mathrm{min}^{-1}$ to $240{ }^{\circ} \mathrm{C}$, where it was maintained for 22.5 min. The operating conditions were set as follows: hydrogen carrier gas at $30 \mathrm{~mL} \mathrm{~min}^{-1}$ flow rate, 300

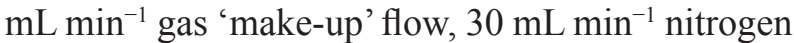
at a flow rate of $1.5 \mathrm{~mL} \mathrm{~min}^{-1}$, injector at $245^{\circ} \mathrm{C}$, detector at $220^{\circ} \mathrm{C}$, and an injection volume of 2.0 $\mu \mathrm{L}$.

\section{Statistical analysis}

Analysis of variance was performed on the quantitative and qualitative characteristics of the carcass, by adopting the following statistical model: $\mathrm{Y}_{i j k l m}=\mu+\mathrm{B}_{i}+\mathrm{N}_{k}+\mathrm{F}_{l}+N F_{k l}+\mathrm{e}_{i j k l m}$, where $\mathrm{Y}_{i j k l m}=$ observation of the animal $m$, within block $i$, level of inclusion $k$ and CG type $l ; \mu=$ a constant associated with all observations; $\mathrm{B}_{i}=$ block effect, where $i=$ $1,2,3,4,5,6,7 ; \mathrm{N}_{k}=\mathrm{CG}$ level effect, where $k=$ $3 \%, 6 \%, 9 \%, 12 \% ; \mathrm{F}_{l}=\mathrm{CG}$ type effect, where $l=$ VCG and MCG; $\mathrm{NF}_{k l}=$ interaction of the inclusion level effect $k$ and CG type $l$; and $\mathrm{e}_{i j k l m}=$ random error associated with the observation. The block was formed by the weight class of the animals, that is, light, intermediate and heavy.

The degrees of freedom associated with the inclusion levels (VCG and MCG) were deployed in orthogonal polynomials, to obtain the regression equations. Dunnett's test (SAMPAIO, 1998) was 
performed using the SAEG statistical package (SAEG, 2007) to compare the results of the CD ( $0 \%$ CG) with each of the inclusion levels (VCG and $\mathrm{MCG}$ ). Analysis regarding the quantitative characteristics and quality of the meat, and the slaughter weight of the animals, was used as a covariate.

\section{Results and Discussion}

The serum parameter results (Tables 2 and 3 ) for the growing and finishing phases showed no interaction $(p>0.05)$ between the level and type of glyceride (VCG and MCG) and the variables glucose, triglycerides, cholesterol and PUN. However, the rate of triglycerides showed a quadratic effect, indicating that the lowest inclusion levels were $4.7 \%$ and $6.2 \%$, which corresponded to 48.8 and $44.6 \mathrm{mg} \mathrm{dL}^{-1}$ in pigs at the growing and finishing stage at the $38^{\text {th }}$ and $36^{\text {th }}$ days of harvest, respectively. These results are in agreement with those presented by Nelson and Cox (2011) because the metabolism of glycerol in the liver can stimulate the synthesis of triglycerides, consequently altering triglyceride plasma concentrations (CARVALHO et al., 2012).

The linear increase in cholesterol and triglyceride obtained by Gallego et al. (2016) in pigs (60-90 $\mathrm{kg}$ ) submitted to diets containing various semipurified glycerin levels $(0.0 \%, 3.5 \%, 7.0 \%, 10.5 \%$ and $14.0 \%$ ) was associated with the metabolism of saturated glycerol, which may not participate in gluconeogenesis and bind to triglycerides for deposition or excretion, increasing these levels in the blood variables (NELSON; COX, 2011).

For the harvest period, in the growing phase, there was a reduction in plasma triglyceride levels and an increase in PUN (harvest on $20^{\text {th }}$ and $38^{\text {th }}$ days). The efficiency of nitrogen utilization in swine may be estimated by measuring blood urea nitrogen (PUN). However, the reduction in PUN also indicates that amino acids were better utilized and there was less deamination of amino acids. In the finishing phase (harvest on $14^{\text {th }}$ and $36^{\text {th }}$ days), a reduction in glucose levels and increase in cholesterol levels were obtained, respectively.

These responses can be attributed to the need for a longer period of adaptation to the animal feed. When there is dietary carbohydrate replacement, a reduction in the plasma concentration of fatty acids occurs, causing a greater use of glucose. This did not occur in our study. Metabolic pathways for urea synthesis by the liver use energy, and an increase in urea or PUN can increase energy expenditure by the liver and concomitantly reduce the glucose that would be destined for other purposes.

Increasing concentrations of plasma cholesterol may be associated with the intake of diets or foods high in cholesterol. Reduced intake of carbohydrates can reduce the concentration of triglycerides in plasma. 


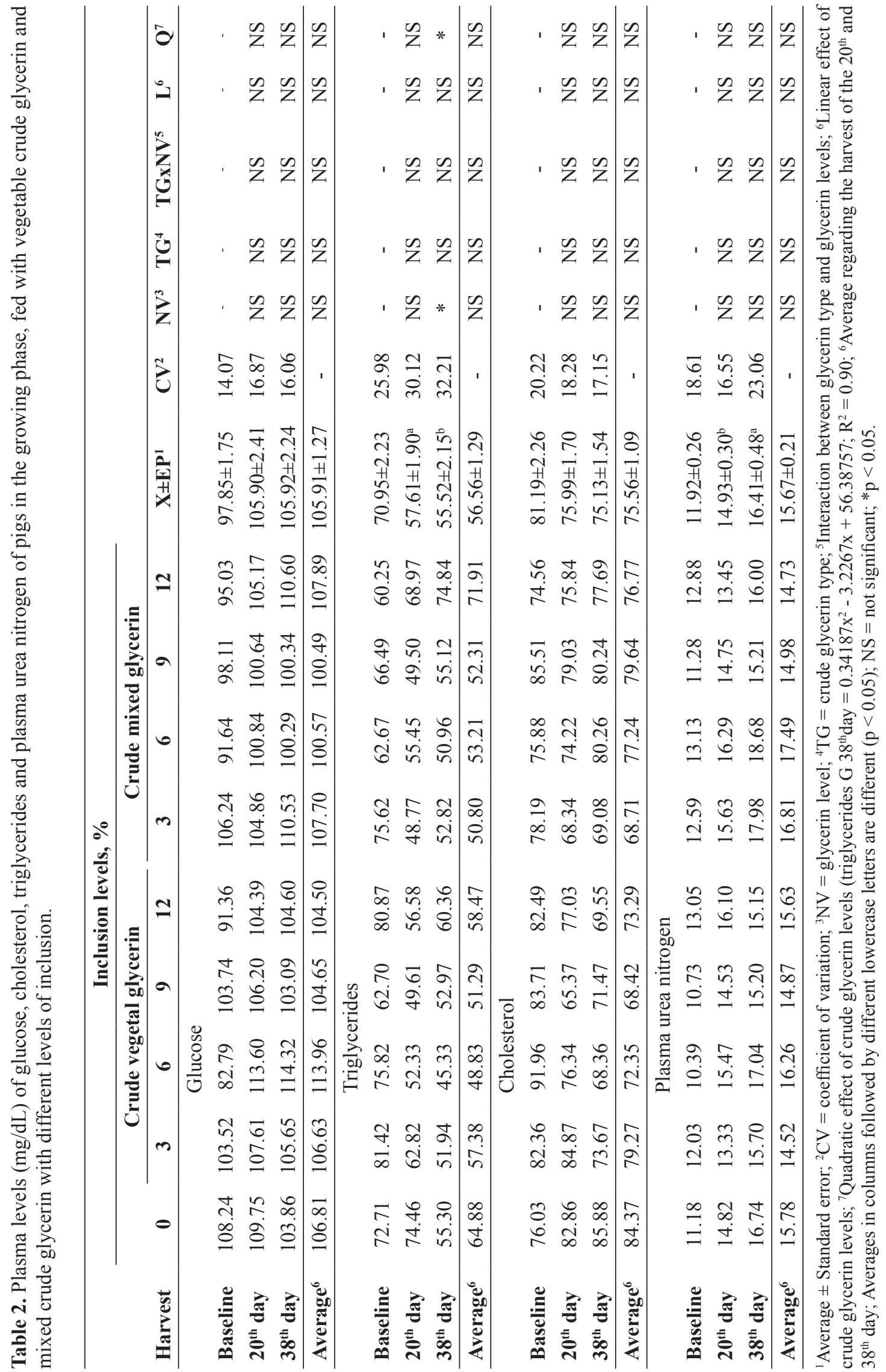

Semina: Ciências Agrárias, Londrina, v. 40, n. 2, p. 919-934, mar./abr. 2019 


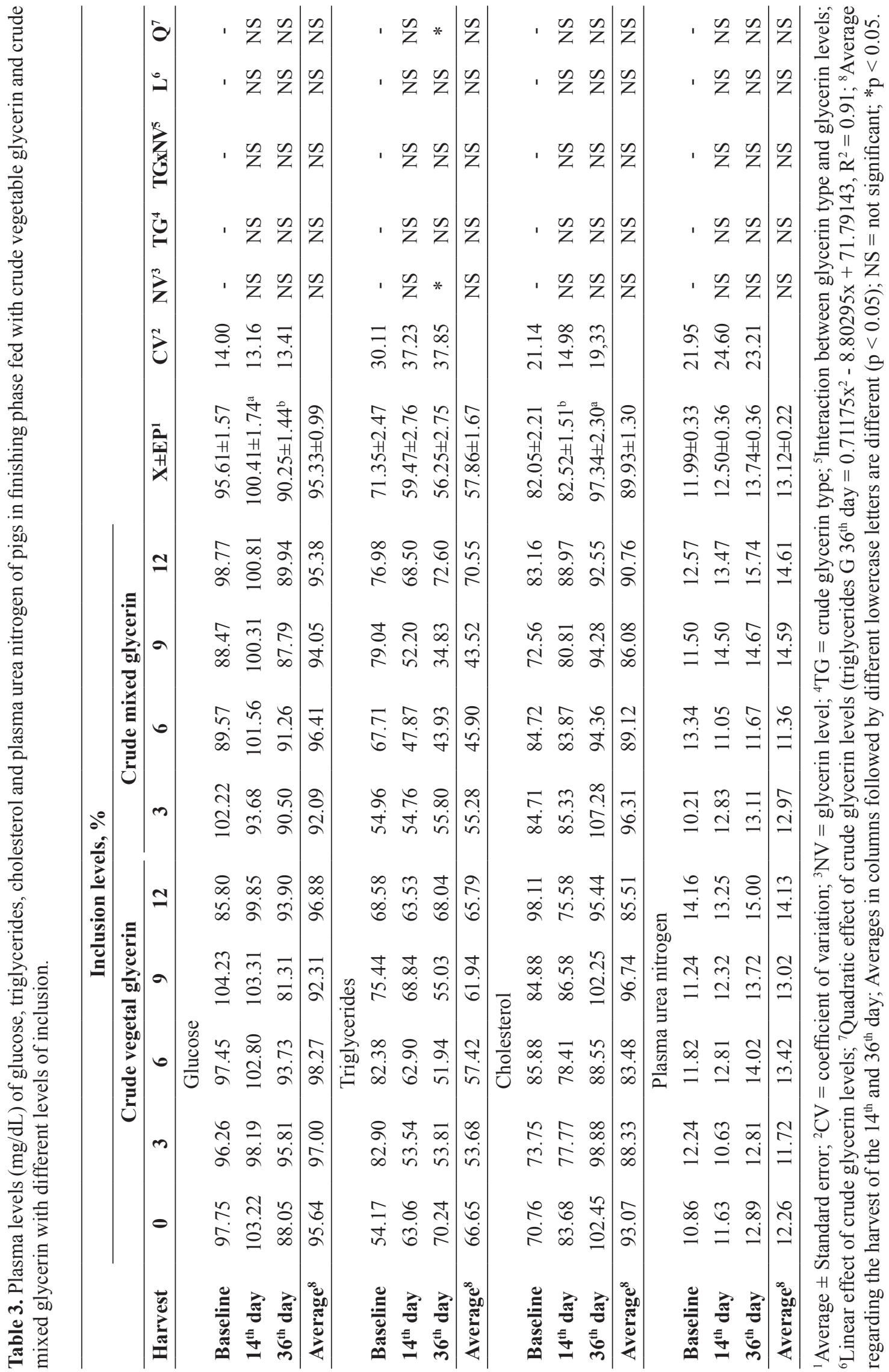




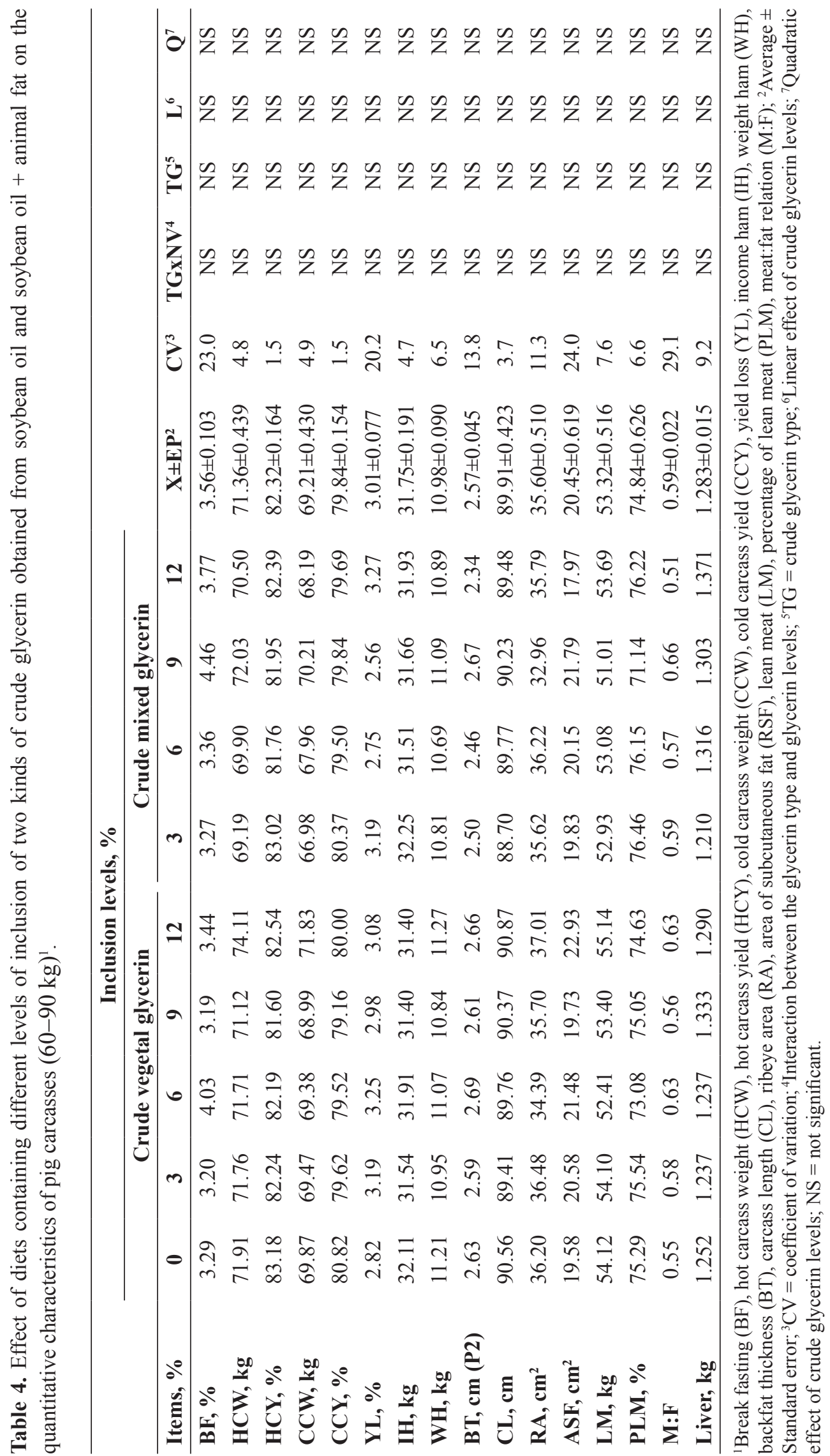


Quantitative carcass characteristics (Table 4) were not influenced by the type of glycerin or inclusion level. Similarly, Dunnett's test revealed no difference between the levels of VCG and MCG included and the $\mathrm{CD}$ for the variables evaluated. These results indicate that the animals can be fed with different glycerides (VCG and MCG) at up to $12 \%$ inclusion, without compromising carcass parameters. Similarly, Della Casa et al. (2009) found no change in carcass yield or lean content from feeding diets with $0 \%, 5 \%$ or $10 \%$ glycerin in the growing and finishing phases.

The results obtained in this study are similar to those presented by Egea et al. (2016), who found no effect on carcass characteristics when ration levels of $0 \%, 5 \%$ and $10 \% \mathrm{CG}$ were used to replace the wheat bran in pig diets. The lack of effects on the quantitative parameters of pig carcasses with the use of CG in the diet can be attributed to its chemical composition and energy; it presents a similar energy value to corn and is an ingredient readily metabolized by the animals (MELO et al., 2014).

Positive results for carcass variables have also been observed previously for the addition of glycerin to pig diets, such as an increase in hot carcass weight (SCHIECK et al., 2010), reduced backfat thickness, and increased eye loin area and water retention capacity (HANCZAKOWSKA et al., 2010).

By feeding a 14\% semi-purified glycerin diet to finishing pigs, Gallego et al. (2016) reported a linear increase in the weight and yield of hot and cold carcasses. The authors highlighted the importance of these results for the pig industry, as improving these variables represents an increase in the profitability of meat production. In this context, they concluded that up to $14 \%$ glycerin can be included without adversely altering carcass characteristics.

There was no interaction among the meat quality variables (Table 5). However, a quadratic behaviour for $\mathrm{pH}_{24 \mathrm{~h}}$ was obtained, with the lowest value attained at $1.05 \%$ CG inclusion. It is known that the final $\mathrm{pH}$ is a determining factor for the quality of meat because it is associated with meat proteins and pigments. Even though there was an effect at $\mathrm{pH}_{24}$, this did not cause a problem in meat quality. Pork is classified as normal when presenting a final $\mathrm{pH}$ value less than 5.9. For a more accurate classification, other attributes are used, such as luminosity values, drip loss, $\mathrm{pH}_{45 \text { min }}$ and $\mathrm{pH}_{24 \mathrm{~h}}$ (BRIDI; SILVA, 2009). Thus, the difference observed for this variable was insufficient to change the other variables associated with meat quality, particularly colour, tenderness and water retention capacity.

In the same line of research, Lammers et al. (2008) achieved similar results, with changes in the final $\mathrm{pH}$ of the meat when including up to $10 \% \mathrm{CG}$ in pig diets. In addition, the authors also found no change in the other variables. They justified that changes in these parameters may be due to several factors, such as the methods used for analysis, genetics and gender, as well as pre- and post-slaughter management, and not only to factors related to diet.

Moreover, Gomide et al. (2012) reported a linear decrease in weight loss in thawing and in shear strength in the meat of pigs fed up to $16 \%$ CG. These variables are important in assessing the quality of meat because an increase in water retention capacity favours its juiciness, an important property of quality, both in meat intended for direct consumption and for industrialization. 


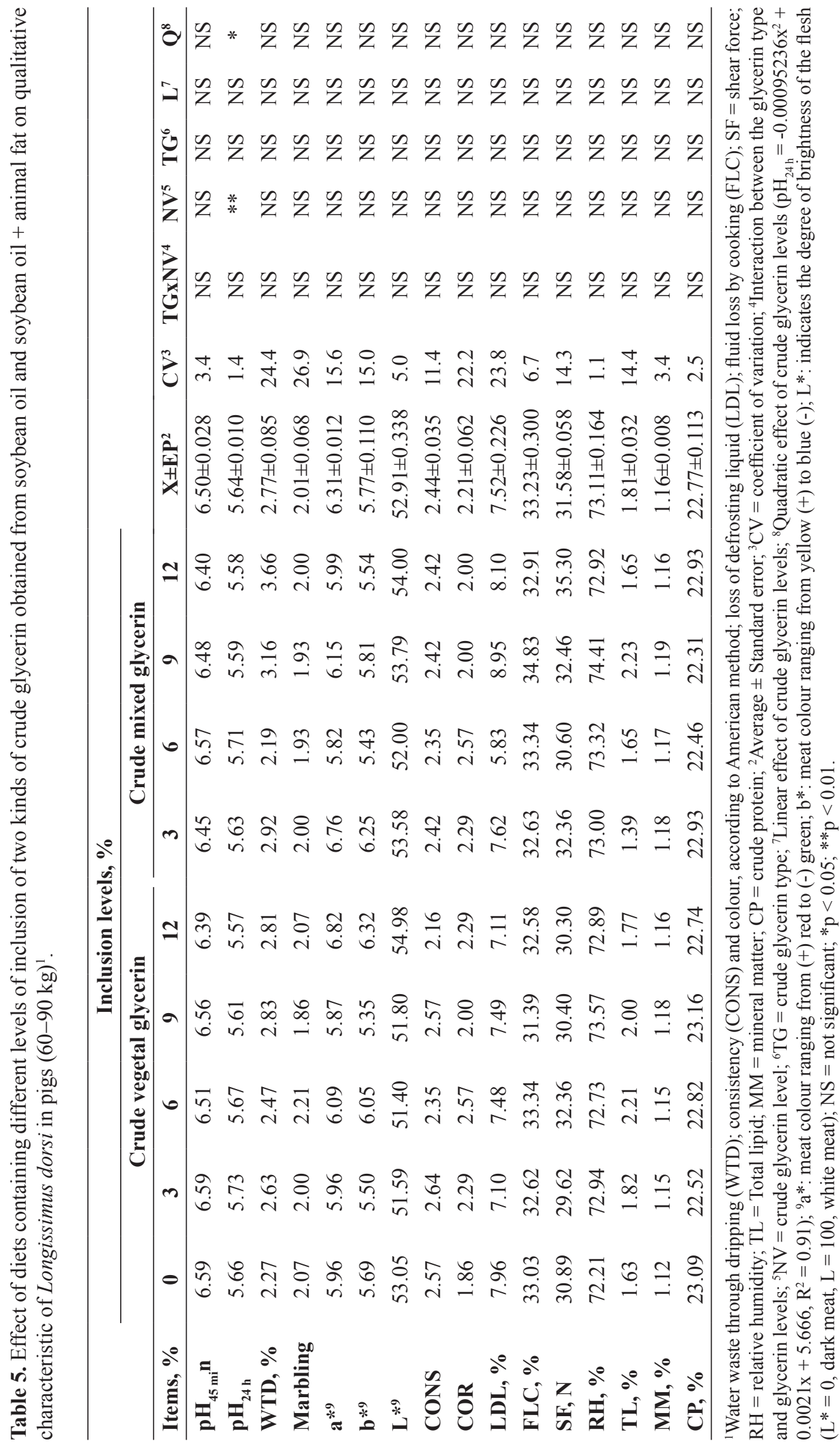


Della Casa et al. (2009) emphasized the importance of water retention in the outcome of the preparation of ham, after studying pigs fed a $10 \%$ CG diet. The authors highlighted that an increase in ham weight loss during curing is attributed to an increase in water loss from the meat, which can adversely affect the quality of the final product.

The polyunsaturated fatty acid levels were influenced by an interaction $(p<0.01)$ between the type of glycerin and the CG inclusion level in the diets (Table 6). Also, a difference in C13:0 and C20:1 fatty acids was found regarding the type of glycerin. However, it was not possible to adjust the results to fit the statistical model. The average values observed for the fatty acids in relation to the type of glycerin were $0.096 \%$ and $0.073 \%(\mathrm{C} 13: 0)$ and $0.022 \%$ and $0.012 \%(\mathrm{C} 20: 1)$ for VCG and MCG,

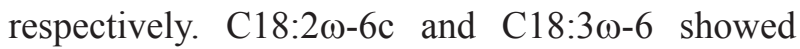
a quadratic effect, indicating that the inclusion levels of $8.85 \%$ and $9.42 \%$ determined the lowest concentrations of these fatty acids, corresponding to $0.015 \%$ and $0.144 \%$, respectively. It is possible that these differences may be associated with the fatty acid profile of the $\mathrm{CG}$, but there is no clear consensus on the effect that feeding CG has on the fatty acid profile of pork lipids.

There are few results in the literature on the fatty acid profile of pigs fed diets containing CG. The first studies carried out with the use of glycerin in pig feed by Lammers et al. (2008) found lower concentrations of linoleic acid (C18:2) when pigs were fed diets containing $10 \% \mathrm{CG}$ than when fed $0 \%$ and 5\% CG diets, and an increasing linear effect on eicosapentaenoic acid (C20:5) with an increase in CG supplementation. According to the authors, there is no clear consensus on the effect that feeding CG has on the fatty acid profile of pork lipids. However, the authors suggested that the differences observed may be associated with the fatty acid composition of the CG or, in particular relation to their study, with the decrease in maize (and consequent decrease in corn oil) due to CG inclusion.

According to Lammers et al. (2008), the apparent disagreement on the effect that feeding glycerin has on the fatty acid profile of pork fat may be due to differences in the amount and profile of fatty acids remaining in the $\mathrm{CG}$, or the reduction in corn due to the addition of $\mathrm{CG}$. 


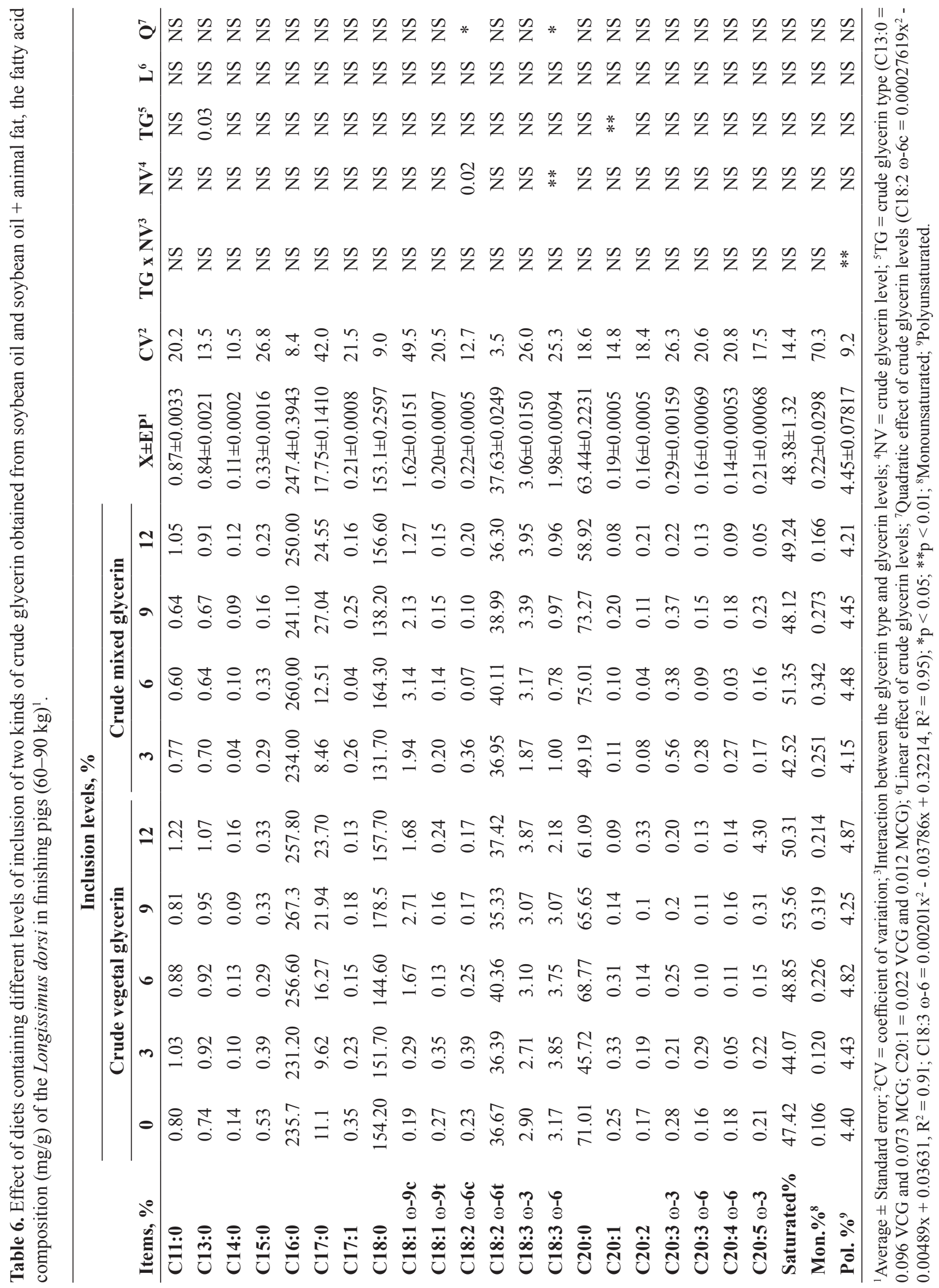




\section{Conclusion}

VCG and MCG can be used at up to $12 \%$ inclusion because they cause no negative effects on carcass characteristics and pig meat quality. Different levels of $C G$ in diets for pigs in the growing and finishing phases influence plasma triglyceride concentrations, $\mathrm{pH}_{24}, L$. dorsi muscle and the fatty acid profile of $\mathrm{C} 18: 2 \omega-6 \mathrm{c}$ and $\mathrm{C} 18: 3 \omega-6$. We conclude that CG is a viable source of dietary energy that is well utilized by pigs.

\section{Acknowledgements}

We thank BSBIOS for providing the glycerin, and $\mathrm{CNPq}$ for the scholarship and research grant.

\section{Conflict of interest}

We certify that there is no conflict of interest with any financial organization regarding the content of the manuscript.

\section{References}

BLIGH, E. G.; DYER, W. J. A Rapid method of total lipid extraction and purification. Canadian Journal of Biochemistry and Physiology, Otawa, v. 37, n. 8, p. 911917, 1959.

BRAGAGNOLO, N.; RODRIGUEZ-AMAYA, D. B. Cholesterol, total lipds and fatty acids in cuts of pork. Food Science and Technology, Campinas, v. 22, n. 1, p. 98-104, 2002.

BRIDI, A. M.; SILVA, C. A. Métodos de avaliação da carcaça e da carne suína. Londrina: Midiograf, 2009. 97 p.

CÂMARA, G.; SOUZA, R. C. M.; FREITAS, U. M.; GARRIDO, J. M. A. SPRING: integrating remote sensing and GIS by object-oriented data modelling. Computers \& Graphics, Amsterdam, v. 20, n. 3, p. 395403, 1996.

CARVALHO, P. L. O.; MOREIRA, I.; MARTINS, E. N.; PIANO, L. M.; TOLEDO, J. B.; COSTA FILHO, C. D. L. Crude glycerine in diets for piglets. Revista Brasileira de Zootecnia, Viçosa, MG, v. 41, n. 7, p. 16541661, 2012.
CARVALHO, P. L. O.; MOREIRA, I.; SCAPINELLO, C.; PIANO, L. M.; GALLEGO, A. G.; MORESCO, G. Crude glycerine in growing and finishing pigs feeding. Semina: Ciências Agrárias, Londrina, v. 34, n. 3, p. 1399-1410, 2013.

CERRATE, S.; YAN, F.; WANG, Z.; COTO, C.; SACAKLI, P.; WALDROUP, P. W. Evaluation of glycerine from biodiesel production as a feed ingredient for broilers. International Journal of Poultry Science, Faisalabad, v. 5, n. 11, p. 1001-1007, 2006.

DELLA CASA, G.; BOCHICCHIO, D.; FAETI, V.; MARCHETTO, G.; POLETTI, E.; ROSSI, A.; GARAVALDI, A.; PANCIROLI, A.; BROGNA, N. Use of pure glycerol in fattening heavy pigs. Meat Science, Amsterdam, v. 81, n. 1, p. 238-244, 2009.

EGEA, M.; LINARES, M. B.; GARRIDO, M. D.; MADRID, J.; HERNÁNDEZ, F. Feeding Iberian $x$ Duroc cross pigs with crude glycerine: effects of diet and gender on carcass and meat quality. Meat Science, Amsterdam, v. 111, n. 1, p. 78-84, 2016.

GALLEGO, A. G.; MOREIRA, I.; CARVALHO, P. L. O.; PERONDI, D.; PASQUETTI, T. J.; GONÇALVES, L. M. P. Neutral semi-purified glycerin in growing and finishing pigs feeding. Italian Journal of Animal Science, Pavia, v. 15, n. 1, p. 87-93, 2016.

GOMIDE, A. P. C.; BRUSTOLINI, P. C.; FERREIRA, A. S.; PAULINO, P. V. R.; LIMA, A. L.; SCOTTÁ, B. A.; RODRIGUES, V. V.; CÂMARA, L. R. A.; MOITA, A. M. S.; OLIVEIRA JÚNIOR, G. M.; FERREIRA, R. C.; FORMIGONI, A. S. Substitution of corn for crude glycerin in diets for finishing pigs. Arquivo Brasileiro de Medicina Veterinária e Zootecnia, Belo Horizonte, v. 64, n. 5, p. 1309-1316, 2012.

HANCZAKOWSKA, E.; WÊGLARZY, K.; SZYMCZYK, B.; HANCZAKOWSKI, P. Effect of adding crude or refined glycerol to pig diets on fattening performance, nutrient digestibility and carcass evaluation. Annals of Animal Science, Kraków, v. 10, n. 1, p. 67-73, 2010.

HANSEN, C. F.; HERNANDEZ, A.; MULLAN, B. P.; MOORE, K.; TREZONA-MURRAY, M.; KING, R. H.; PLUSKE, J. R. A chemical analysis of samples of crude glycerol from the production of biodiesel in Australia, and the effects of feeding crude glycerol to growingfinishing pigs on performance, plasma metabolites and meat quality at slaughter. Animal Production Science, Melbourne, v. 49, n. 2, p. 154-161, 2009.

KERR, B. J.; WEBER, T. E.; DOZIER, W. A.; KIDD, M. T. Digestible and metabolizable energy content of crude glycerin originating from different sources in 
nursery pigs. Journal of Animal Science, Champaign, v. 87, n. 12, p. 4042-4049, 2009.

KIJORA, C.; KUPSCH, S. D. Evaluation of technical glycerols from biodiesel production as a feed component in fattening of pigs. European Journal of Lipid Science and Technology, Weinheim, v. 98, n. 7-8, p. 240-245, 1996.

LAMMERS, P. J.; KERR, B. J.; WEBER, T. E.; BREGENDAHL, K.; LONERGAN, S. M.; PRUSA, K. J.; AHN, D. U.; STOFFREGEN, W. C.; DOZIER, W. A.; HONEYMAN, M. S. Growth performance, carcass characteristics, meat quality, and tissue histology of growing pigs fed crude glycerin-supplemented diets. Journal of Animal Science, Champaign, v. 86, n. 11, p. 2962-2970, 2008.

MELO, D. S.; FARIA, P. B.; CANTARELLI, V. S.; ROCHA, M. F. M.; PINTO, A. M. B. G.; RAMOS, E. M. Meat quality of swine with the use of glycerin in feeding. Arquivo Brasileiro de Medicina Veterinária e Zootecnia, Belo Horizonte, v. 66, n. 2, p. 583-592, 2014.

MOUROT, J. Utilisation du glycérol en alimentation porcine. Productions Animales, Paris, v. 22, n. 5, p. 409414, 2009.

MOUROT, J.; AUMAITRE, A.; MOUNIER, A.; PEINIAU, P.; FRANÇOIS, A.; PEYRONNET, C.; JAMET, J. P. Effets du glycerol alimentaire sur les performances de croissance et la qualite de la viande chez le porc large white. Journées de la Recherche Porcine en France, Paris, v. 25, n. 3, p. 29-35, 1993.

MOUROT, J.; AUMAITRE, A.; MOUNIER, A.; PEINIAU, P.; FRANÇOIS, A. C. Nutritional and physiological effects of dietary glycerol in the growing pig. Consequences on fatty tissues and post mortem muscular parameters. Livestock Production Science, Amsterdam, v. 38, n. 3, p. 237-244, 1994.
NATIONAL PORK PRODUCERS COUNCIL NPPC. Procedures to evaluate market hogs. $3^{\text {th }}$ ed. Des Moines: NPPC, 1991. 16 p.

NELSON, D. L.; COX, M. M. Lehninger's principles of biochemistry. $5^{\text {th }}$ ed. Porto Alegre: Artmed, 2011. $1725 \mathrm{p}$.

RAMOS, E. M.; GOMIDE, L. A. M. Evaluation of meat quality: fundamentals and methodologies. Viçosa, MG: UFV, 2007. 599 p.

RIVALDI, J. D.; SARROUH, B. F.; FIORILO, R.; SILVA, S. D. Glycerol of biodiesel: biotechnological strategies for glycerol utilization derived from biodiesel production. Biotecnologia, Ciência e Desenvolvimento, Brasília, v. 10, n. 37, p. 44-51, 2007.

ROSTAGNO, H. S.; ALBINO, L. F. T.; DONZELE, J. L.; GOMES, P. C.; OLIVEIRA, R. F.; LOPES, D. C.; FERREIRA, A. S.; BARRETO, S. L. T.; EUCLIDES, R. F. Brazilian tables for poultry and swine: composition of feedstuffs and nutritional requirements. $3^{\text {th }}$ ed. Viçosa, MG: UFV, 2011. 252 p.

SAMPAIO, I. B. M. Statistics applied to animal experimentation. Belo Horizonte: UFMG, 1998. 221 p.

SCHIECK, S. J.; SHURSON, G. C.; KERR, B. J.; JOHNSTON, L. J. Evaluation of glycerol, a biodiesel coproduct, in grow-finish pig diets to support growth and pork quality. Journal of Animal Science, Champaign, v. 88, n. 12, p. 3927-3935, 2010.

SILVA D. J.; QUEIROZ, A. C. Food analysis (chemical and biological methods). $3^{\text {th }}$ ed. Viçosa, MG: UFV, 2002. $235 \mathrm{p}$.

SISTEMA PARA ANÁLISES ESTATÍSTICAS - SAEG. Análises estatísticas. Versão 9.1: Fundação Arthur Bernardes. Viçosa, MG: Universidade Federal de Viçosa, 2007. 
